\title{
Flora arbórea da bacia do rio Tibagi (Paraná, Brasil): Celastrales sensu Cronquist
}

\author{
Ricardo Augusto Gorne Viani ${ }^{1,3}$ e Ana Odete Santos Vieira ${ }^{2}$
}

Recebido em 3/01/2006. Aceito em 10/11/2006

\begin{abstract}
RESUMO - (Flora arbórea da bacia do rio Tibagi (Paraná, Brasil): ordem Celastrales sensu Cronquist). Este trabalho estudou, por meio de coleções de herbários, os representantes arbóreos da ordem Celastrales sensu Cronquist, encontrados na bacia do rio Tibagi, estado do Paraná, Brasil. Esta bacia hidrográfica, subdividida em três zonas de norte para sul, baixo Tibagi (BT), médio Tibagi (MT) e alto Tibagi (AT), apresenta diferentes condições ambientais e tipos de vegetação ao longo de sua extensão. A ordem Celastrales está representada na bacia estudada por 15 espécies arbóreas, pertencentes às famílias Aquifoliaceae, Celastraceae e Icacinaceae. Icacinaceae conta com apenas duas espécies, Citronella gongonha e C. paniculata, sendo a primeira distinta pelo ovário glabro e folhas geralmente com espinhos. Aquifoliaceae contém seis espécies: Ilex brasiliensis, I. brevicuspis, I. chamaedryfolia, I. dumosa, I. paraguariensis e I. theezans, que ocorrem preferencialmente no AT e MT e se distinguem pela dimensão, revestimento, ápice e margem da folha e pela morfologia das sépalas. Celastraceae está representada por sete espécies pertencentes a dois gêneros, Plenckia populnea, espécie de cerrado, encontrada apenas no MT e seis espécies de Maytenus (M. aquifolia, M. dasyclada, M. evonymoides, M. ilicifolia, M. robusta e M. salicifolia), com distinção baseada principalmente no tipo de margem e dimensão das folhas, forma do ramo e número de flores por inflorescência.
\end{abstract}

Palavras-chave: flora, Aquifoliaceae, Icacinaceae, Celastraceae, bacia do rio Tibagi

\begin{abstract}
Tree flora of the Tibagi river basin (Paraná, Brazil): Celastrales sensu Cronquist). A study of the tree species of the order Celastrales sensu Cronquist from the Tibagi river basin, Paraná state, Brazil, is presented, based on herbarium material. This basin is subdivided into three zones, from north to south: lower Tibagi (BT), mid Tibagi (MT) and upper Tibagi (AT), each with different environmental conditions and vegetation types. The order Celastrales is represented in the basin by 15 tree species belonging to three families: Aquifoliaceae, Celastraceae and Icacinaceae. Icacinaceae has only two species, Citronella gongonha and C. paniculata. The former is distinguished by a glabrous ovary and leaves that usually bear thorns. Aquifoliaceae has six species: Ilex brasiliensis, I. brevicuspis, I. chamaedryfolia, I. dumosa, I. paraguariensis and I. theezans. These species are found mainly in AT and MT and are distinguished by leaf size, indument, apices and margins, and by sepal features. Celastrales is represented by seven species and two genera; Plenckia populnea, a Brazilian savannah species found only in MT, and six species of Maytenus (M. evonymoides, M. robusta, M. dasyclada, M. salicifolia, M. ilicifolia and M. aquifolia) distinguished by leaf size and margins, branch shape and number of flowers per inflorescence.
\end{abstract}

Key words: flora, Aquifoliaceae, Icacinaceae, Celastraceae, Tibagi river basin

\section{Introdução}

O Estado do Paraná, na Região Sul do Brasil, contava em 2000 com uma cobertura florestal nativa correspondente a apenas $19,63 \%$ de sua área total (Fundação SOS Mata Atlântica \& INPE 2002), composta principalmente por fragmentos florestais isolados e degradados. A mesma situação ocorre por toda bacia hidrográfica do rio Tibagi, onde a cobertura florestal nativa foi reduzida em aproximadamente $96 \%$, restando poucos remanescentes preservados (Medri et al. 2002), sem contar a degradação de ecossistemas não florestais, como cerrados e campos naturais, freqüentemente negligenciados e por isso, também severamente afetados pelas atividades antrópicas.

Além da eminente necessidade de recuperação da paisagem, destaca-se que até 1990 as florestas da bacia do rio Tibagi, uma das mais importantes da região, eram pouco conhecidas floristicamente, com poucos registros de coleta para a região (Dias et al. 2002). Diante disto, surgiu em 1989, o projeto "Aspecto da fauna e flora da bacia do rio Tibagi". Um de seus subprojetos, "Flora arbórea do rio Tibagi", do qual faz parte este trabalho, tem por objetivo levantar e estudar a composição florística da bacia, fornecendo importantes subsídios para a conservação dos recursos

\footnotetext{
1 Universidade Estadual de Campinas, Instituto de Biologia, Departamento de Botânica, Programa de Pós-graduação em Biologia Vegetal, C. Postal 6109, 13083-970 Campinas, SP, Brasil

2 Universidade Estadual de Londrina, Departamento de Biologia Animal e Vegetal, C. Postal 6001, 86051-990 Londrina, PR, Brasil

3 Autor para correspondência: viani@unicamp.br
} 
naturais e recomposição de áreas com vegetação nativa (Medri et al. 2002). Até o momento, foram listadas 547 espécies arbóreas para a Bacia do rio Tibagi, distribuídas em 239 gêneros e 80 famílias (Dias et al. 2002).

A ordem Celastrales, sensu Cronquist (1988), é constituída por dez famílias, com espécies predominantemente lenhosas de regiões tropicais e subtropicais (Barroso et al. 1991). As primeiras obras importantes, com relatos e descrições sobre espécies brasileiras pertencentes a esta ordem foram feitas por Reissek (1861), Loesener (1942a; 1942b) e Sleumer (1942). Para o Brasil, segundo a classificação proposta por Cronquist (1988), a ordem Celastrales contém cinco famílias, sendo que três destas, Aquifoliaceae, Celastraceae e Icacinaceae, contam com representantes arbóreos na bacia do rio Tibagi. Aquifoliaceae é reconhecida pelas flores díclinas e Icacinaceae pelas flores monóclinas, ambas sem disco nectarífero, já Celastraceae apresenta flores monóclinas com disco nectarífero bem desenvolvido.

Ressalta-se que os últimos sistemas de classificação propostos para as angiospermas, baseados principalmente em técnicas de biologia molecular, têm indicado novas posições filogenéticas para as famílias citadas acima. De acordo com o sistema de classificação APG II (APG 2003), Celastraceae (com incorporação de Hippocrateaceae) pertence à ordem Celastrales (Eurosids I), Aquifoliaceae à ordem Aquifoliales (Euasterids II) e Icacinaceae pertence à Euasterids I, com posição ainda incerta quanto à ordem. Devido a estas incertezas quanto às posições filogenéticas dos sistemas moleculares e por ser o sistema de Cronquist ainda conhecido, adotou-se este último nesse trabalho.

Dessa forma, o objetivo desse trabalho foi descrever morfologicamente e elaborar chaves de identificação das espécies arbóreas da ordem Celastrales sensu Cronquist, encontradas na bacia do rio Tibagi, Paraná, contribuindo para o melhor conhecimento deste grupo de plantas e da flora regional como um todo.

\section{Material e métodos}

Para o presente estudo foram consultadas exsicatas depositadas no herbário FUEL, provenientes de coletas sistemáticas realizadas na região da bacia do rio Tibagi, a partir de 1985, acrescido de materiais oriundos dos herbários ESA, HUEM, HUPG, MBM, UEC, UPCB (siglas segundo Holmgren \& Holmgren 2005), da Fundação Faculdades Luiz Meneghel, Bandeirantes-PR (CBT) e do Centro de Pesquisas em
Florestas da EMBRAPA, Colombo-PR (HFC).

$\mathrm{O}$ trabalho constou de fichamento dos materiais examinados, identificação e descrição das famílias, gêneros e espécies, bem como confecção de chaves analíticas de identificação de gêneros e espécies. Dados como altura dos indivíduos, fenologia (data de floração e frutificação), coloração de flores e frutos e particularidades de cada espécie foram obtidos por meio das fichas de coleta.

Os termos morfológicos utilizados para as descrições das espécies seguiram os incluídos nos tratamentos recentes para as famílias no Brasil, Aquifoliaceae (Groppo \& Pirani 2002), Celastraceae (Carvalho-Okano 2005) e Icacinaceae (Mazine et al. 2005). As medições dos caracteres vegetativos e dos frutos foram efetuadas no material seco e das flores em material reidratado. Para a citação dos materiais examinados foi selecionada uma exsicata representativa da espécie, em cada município de ocorrência. Uma listagem completa dos materiais examinados de cada espécie encontra-se disponível com os autores. Foram utilizadas as seguintes abreviações: b. (material com botões florais), fl. (material com flores), fr. (material com frutos), veg. (material em estado vegetativo) e s.n. (sem número de coletor). Como materiais adicionais foram citadas as exsicatas utilizadas para a confecção das ilustrações, quando estas não estavam no material selecionado da espécie e também materiais de municípios localizados fora da bacia do rio Tibagi. Porém ressalta-se que, com exceção das características do fruto em Ilex chamaedryfolia (espécie sem material examinado em frutificação para os municípios da área de estudo), as demais observações realizadas em exsicatas de municípios localizados fora da bacia do rio Tibagi não foram utilizadas para a descrição morfológica das espécies.

Área de estudo - A bacia do rio Tibagi $\left(22^{\circ} 30^{\prime}-26^{\circ} \mathrm{S}\right.$ e $49^{\circ} 30^{\prime}-52^{\circ} \mathrm{W}$ ), localizada no estado do Paraná, conta com 54 municípios e cobre cerca de $25.000 \mathrm{~km}^{2}$ (Fig.1). É a terceira maior bacia hidrográfica do estado, ocupando $13 \%$ de sua área total. O rio Tibagi nasce em Palmeira, no segundo planalto e corre em direção ao terceiro planalto, desembocando no rio Paranapanema, no município de Primeiro de Maio. Sua bacia hidrográfica é subdividida em três zonas de norte para o sul, o baixo Tibagi (BT), o médio Tibagi (MT) e o alto Tibagi (AT), com altitudes entre 350-1.150 m e climas Cfa ou Cfb. Ao longo de seus $550 \mathrm{~km}$ de extensão são encontrados os seguintes tipos de vegetação: Floresta Estacional Semidecidual e Decidual 


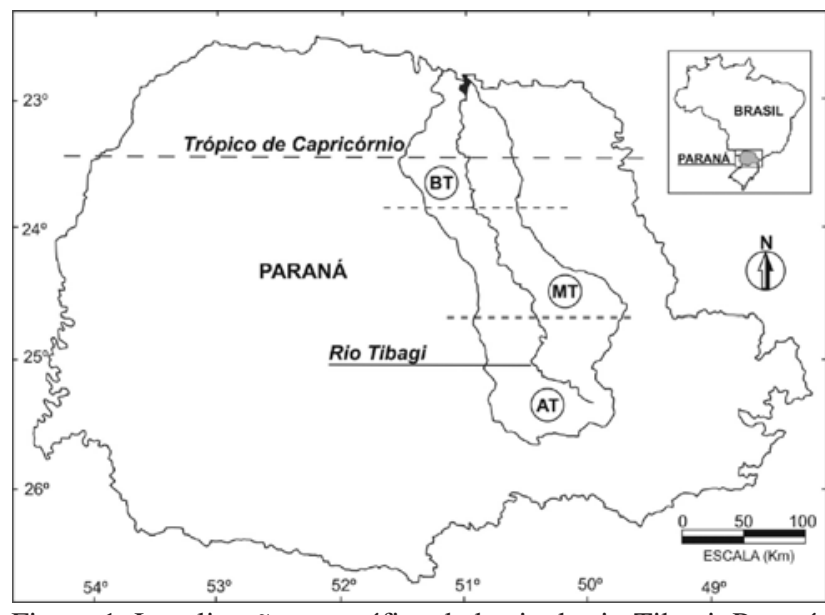

Figura 1. Localização geográfica da bacia do rio Tibagi, Paraná, Brasil, com suas subdivisões em AT: alto tibagi, MT: médio Tibagi e BT: baixo Tibagi.

(BT, MT), Floresta Ombrófila Mista (Floresta de Araucaria) (MT, AT), cerrados (MT), campos (AT) e florestas ripárias (BT, MT e AT) (Torezan 2002).

\section{Resultados e discussão}

\section{Aquifoliaceae}

A família Aquifoliaceae possui distribuição cosmopolita e inclui um único gênero, Ilex L., com aproximadamente 400 espécies, das quais cerca de
50 ocorrem no Brasil (Souza \& Lorenzi 2005). Na bacia do rio Tibagi foram examinados materiais de seis espécies, I. brasiliensis (Spreng.) Loes., I. brevicuspis Reissek, I. chamaedryfolia Reissek, I. dumosa Reissek, I. paraguariensis A.St.-Hil. e I. theezans Mart. ex Reissek. Estas espécies são importantes e mais freqüentes dentro da Floresta Ombrófila Mista (Floresta de Araucaria).

\subsection{Ilex L.}

Arbustos ou árvores, dióicos; ramos angulosos no ápice, geralmente escuros no material seco. Folhas alternas, simples, pecioladas; nervura primária proeminente na face abaxial. Inflorescência nas axilas das folhas ou na base de ramos jovens, dicásios, fascículos corimbóides, racemos ou flores solitárias; pedicelo com bractéolas na base; flores díclinas, com estruturas rudimentares do outro sexo, diclamídeas, 45-6 meras, isostêmones, actinomorfas; sépalas castanhas, unidas, com a margem às vezes ciliada; pétalas creme ou creme esverdeadas, unidas na base; estames alternos às pétalas, aderidos à base da corola, com deiscência longitudinal; ovário súpero, subgloboso, lóculos 4-6, um óvulo por lóculo; estigma séssil; pistilódio subgloboso ou cônico. Fruto drupáceo, com cálice e estigma persistentes, com 2-9 pirenos lisos ou sulcados no dorso.

Chave de identificação de espécies de Ilex para a bacia do rio Tibagi

1. Folhas com margem inteira ou com dentes próximo ao ápice

2. Folhas densamente pubescentes, ao menos na face adaxial

1.1.1. I. brasiliensis

2. Folhas glabras ou com esparsa pubescência, concentrada na nervura principal

3. Ápice foliar freqüentemente acuminado, lâmina membranácea a cartácea, frutos 3-4 mm diâmetro

1.1.2. I. brevicuspis

3. Ápice foliar obtuso ou agudo, lâmina coriácea, fruto 5-9 mm diâmetro

1.1.6. I. theezans

1. Folhas com margem crenada ou serreada

4. Lâmina foliar 2,2-5,1 cm de largura, sépalas com a margem não ciliada

1.1.5. I. paraguariensis

4. Lâmina foliar 0,3-2,1 cm de largura, sépalas com margem ciliada

5. Lâmina foliar obovada ou estreitamente elíptica, 3-8 mm de largura, séssil ou com pecíolo de até $3 \mathrm{~mm}$ 1.1.3. I. chamaedryfolia

5. Lâmina foliar elíptica, 10-21 mm de largura, pecíolo 3-10 mm 1.1.4. I. dumosa

1.1.1. Ilex brasiliensis (Spreng.) Loes., Nat. Pflanzenfam. 1: 220. 1897.

Fig. 2-3

Arbustos ou árvores, 1,5-8 m; ramos jovens pubescentes. Pecíolo pubescente, 2-11 mm; lâmina pubescente à densamente pubescentes na face abaxial, cartácea a coriácea, 1,5-6,2×0,8-3,3 cm, elíptica ou obovada; base aguda a obtusa, simétrica; ápice obtuso, agudo ou acuminado, ocasionalmente mucronado; margem inteira, revoluta; nervura primária pubescente em ambas as faces. Inflorescência em dicásios 3-floros; eixo da inflorescência pequeno, ca. $5 \mathrm{~mm}$; pedicelo 
2-4 mm, pedúnculo 2-7 mm. Flores 5(6)-meras; sépalas pubescentes, $1 \times 1-2 \mathrm{~mm}$, triangulares; pétalas glabras, 1-2×2-3 mm, elípticas, ovais ou obovadas; estames $3 \mathrm{~mm}$, filetes $2 \mathrm{~mm}$, antera ca. $1 \mathrm{~mm}$; pistilódio cônico, rostrado, menor que $2 \mathrm{~mm}$ diâm. e 1-2 mm alt. Fruto globoso, vináceo quando maduro, 5-6 mm; pirenos 4-6, menores que $2 \mathrm{~mm}$.

Material selecionado: BRASIL. Paraná: Palmeira, 14/II/1991, fr., Silva \& Barbosa 934 (FUEL, MBM). Ponta Grossa, 5/X/1989, b. fl., Cervi \& Hatschbach 2800 (MBM). São Jerônimo da Serra, 12/VI/1999, veg., Viani et al. 2 (FUEL). Tamarana, 8/VI/1999, fr., Estevan et al. 6 (FUEL). Tibagi, 13/IX/1997, fr., Yasumoto \& Breton s.n. (FUEL21234, MBM 239718). Ventania, 30/III/1999, fr., Francisco \& Fadelli s.n. (FUEL24837).

Material adicional: BRASIL. Paraná: Colombo, 8/VI/1995, fr., Maschio \& Souza 39 (FUEL). Tamarana, 22/IX/1998, b. fl., Francisco \& Alves s.n. (FUEL21581); 6/XI/1989, fr., Francisco \& Pavão s.n. (FUEL24832).

Ocorre no Brasil (Goiás, Distrito Federal, Mato Grosso do Sul, Minas Gerais, Paraná e São Paulo) e Paraguai (Giberti 1994; Groppo \& Pirani 2002). Na bacia do rio Tibagi é encontrada principalmente no AT e MT. I. brasiliensis foi coletada com flores de setembro a novembro e com frutos em maio, junho, de setembro a dezembro e de fevereiro a março. Espécie semelhante à I. theezans, diferenciando-se pelo indumento dos seus ramos e folhas. É uma espécie preferencialmente higrófita, encontrada com maior frequiência em áreas sujeitas ao alagamento, como várzeas e margens de rios. S. Andrews (Royal Botanic Gardens, Kew), em material identificado de herbário, considera a existência de variedades de I. brasiliensis, com I. brasiliensis var. parvifolia (Reissek) Loes e I. brasiliensis var. pubiflora (Reissek) Loes., ambas registradas para a bacia do rio Tibagi e com limites taxonômicos tênues, que devem ser revistos em um estudo de revisão do gênero.

1.1.2. Ilex brevicuspis Reissek, Fl. bras. 11(1): 56, t. 13, f. 2.1861.

Fig. 4-5

Árvores, 4,5-23 m; ramos novos pubescentes, lenticelados. Pecíolo esparsamente pubescente, 0,3-1 cm; lâmina glabra, membranácea a cartácea, membranácea e escurecida quando nova, 2,7-6,7x 1-2,8 cm, elíptica; base simétrica, aguda; ápice agudo, acuminado ou ocasionalmente obtuso; margem inteira ou com mais freqüência serreada na porção superior, nervura primária esparsamente pubescente na face abaxial. Inflorescência em fascículos 3-7 floros, dicásios solitários ou não; pedicelo 2-6 mm; pedúnculo 3-12 mm. Flores 4-5 meras; sépalas glabras, $1 \times 1 \mathrm{~mm}$, ovais; pétalas glabras, 2-3×1-2 mm, elípticas ou ovais; estames $2-3 \mathrm{~mm}$, filete ca. $2 \mathrm{~mm}$, antera ca. $1 \mathrm{~mm}$; pistilódio cônico, rostrado, lobulado, ca. $1 \mathrm{~mm}$. Fruto globoso, 3-4 mm; pirenos 4, os menores com $1 \mathrm{~mm}$.

Material selecionado: BRASIL. Paraná: Curiúva, 24/XI/1999, fr., Pavão et al. s.n. (FUEL27687). Irati, 20/IV/1983, fr., Pirani \& Yano 574 (FUEL). Londrina, 23/VI/1994, b., Chagas e Silva 1712 (FUEL). Ortigueira, 6/XI/1998, b. fl., Pavão \& Francisco s.n. (FUEL24833, MBM84833). Ponta Grossa, 3/X/1988, b., Sessegolo 79 (MBM). São Jerônimo da Serra, 30/X/1998, b. fl., Francisco et al. s.n. (FUEL22306, MBM239720). Teixeira Soares: IV/1995, fr., Carvalho 239 (ESA, HFC). Telêmaco Borba, 2/VIII/1991, fr., Soares-Silva et al. 285 (FUEL). Tibagi, 16/I/1991, b. fl., Chagas e Silva 1568 (FUEL).

Material adicional: BRASIL. Paraná: Telêmaco Borba, 20/XI/1989, b. fl., Colli et al. s.n. (FUEL7654).

Ocorre no Brasil, em Minas Gerais, São Paulo e principalmente nos estados sulinos, Argentina e Paraguai (Groppo \& Pirani 2002). Na Bacia do rio Tibagi é encontrada nas três subregiões, principalmente no MT e BT. Foi coletada com flores em outubro, novembro, janeiro e abril e com frutos em novembro, fevereiro a abril e agosto. Dentre as espécies do gênero na bacia, I. brevicuspis é a maior árvore, sendo encontrada tanto em mata alta e úmida quanto no subbosque da floresta. É utilizada como adulterante de erva-mate (Edwin \& Reitz 1967). O pistilódio em flores masculinas e a margem, o ápice e a textura foliar são características marcantes da espécie. I. brevicuspis é morfologicamente muito próxima de I. microdonta Reissek, porém esta última se distingue, vegetativamente, pela folhas mais espessas e margem serreada (Macedo \& Chiea 1986).

1.1.3. Ilex chamaedryfolia Reissek, Fl. bras. 11(1): 73. 1861.

Fig. 6

Arbusto ou arvoreta; ramos jovens estriados, pubescentes. Pecíolo pubescente, até $5 \mathrm{~mm}$; lâmina glabra, coriácea, $0,8-6 \times 0,3-1,1 \mathrm{~cm}$, frequentemente com glândulas punctiformes escuras na face abaxial, obovada ou estreitamente elíptica; base aguda, às vezes aladamente decurrente pelo comprimento do pecíolo; ápice agudo a obtuso, às vezes mucronado; margem revoluta, crenada a serreada, ao menos da metade para 
o ápice, nervura primária glabra em ambas as faces. Inflorescência fasciculada ou menos freqüentemente flores solitárias, até $1,3 \mathrm{~cm}$; pedicelo $1-3 \mathrm{~mm}$, pedúnculo 1-3 mm. Flores 4-meras; sépalas glabras, $1 \times 1 \mathrm{~mm}$, triangulares ou ovais, margem freqüentemente ciliada; pétalas $2,5 \times 2 \mathrm{~mm}$, ovais a elípticas; estames $2-3 \mathrm{~mm}$, filete 1-2 mm, antera ca. $1 \mathrm{~mm}$; pistilódio discóideachatado, sem estigma, ca. $1 \mathrm{~mm}$. Fruto globoso, arroxeado quando maduro, 2-3 $\mathrm{mm}$; pirenos 4 , menores que $1 \mathrm{~mm}$.

Material selecionado: BRASIL. Paraná: Palmeira, 21/XI/1971, fr., Hatschbach 28114 (MBM). Ponta Grossa, 10/V/1992, fl., Moro 973 (FUEL, UPCB).

Material adicional: BRASIL. Minas Gerais: Poços de Caldas, 30/X/1981, fr, Leitão-Filho et al. 1404 (UEC); 2/XII/1981, fr., Pereira 1509 (UEC). Paraná: Ponta Grossa, 10/X/1992, b. fl., Schiesinsky 26 (UEPG).

Comentários: no Brasil ocorre em Minas Gerais, Goiás, São Paulo e Região Sul (Edwin \& Reitz 1967). $\mathrm{Na}$ bacia do rio Tibagi foi encontrada apenas no AT. Espécie caracterizada principalmente pelas dimensões reduzidas de suas folhas, I. chamaedryfolia foi coletada com flores em maio, outubro e novembro e com frutos em novembro. Utilizada como sucedâneo da erva-mate, ocorre em campos com solos pedregosos e pouco profundos (Edwin \& Reitz 1967). Embora se diferencie de I. dumosa pelas folhas menores, subsésseis e obovais, a delimitação desses táxons não é clara, sendo necessários estudos mais aprofundados para isso (Groppo \& Pirani 2002).

\subsubsection{Ilex dumosa Reissek, Fl. bras. 11(1): 64. 1861.} Fig. 7-8

Arvoretas ou árvores, 2-7(18) m; ramos jovens esparsamente pubescentes, quando novos pubescentes. Pecíolo pubescente, 2-6 mm; lâmina glabra, coriácea, 2,9-6,6×1-2,1 cm, com glândulas punctiformes escuras freqüentes na face abaxial, elíptica; base aguda; ápice obtuso a agudo; margem crenada a serrada, revoluta; nervura primária esparsamente pubescente. Inflorescência em racemos, tirsos ou fascículos corimbóides; pedicelo 2-3 mm; pedúnculo até $5 \mathrm{~mm}$. Flores 4-meras; sépalas glabras, 1-2 mm, triangulares ou ovais, margem ciliada; pétalas 2-3×2 mm, ovais ou elípticas; estames $2 \mathrm{~mm}$, filete 1 $\mathrm{mm}$, antera ca. $1 \mathrm{~mm}$; estaminódios até $1 \mathrm{~mm}$; ovário subgloboso, 1-2 mm, lóbulos inconspícuos, estigma bem desenvolvido, tetralocular; pistilódio achatado, menor que $1 \mathrm{~mm}$. Fruto globoso, 3-4 mm; pirenos 4, achatados dorsalmente.

Material selecionado: BRASIL. Paraná: Castro, 15/VIII/1973, veg., Hatschbach 32323 (MBM). Irati, 25/IX/1972, b., Carvalho 22 (MBM). Palmeira, 28/XI/1993, fr., Chagas e Silva 1659 (FUEL, MBM). Porto Amazonas, 6/XII/1996, fr., Souza \& Mendes s.n. (FUEL20118, MBM23924). Reserva, 10/XI/1998, fl., Francisco \& Alves s.n. (FUEL22354, MBM239722). Teixeira Soares, 1/XII/1991, veg., Chagas e Silva et al. s.n. (FUEL17315). Telêmaco Borba, 14/XI/1952, fl., Hatschbach 2858 (MBM). Tibagi, 14/IX/1996, fl. fr., Silveira et al. s.n. (FUEL20168).

Material adicional: BRASIL. Paraná: Quatro Barras, 13/IV/1994, fr., Silva \& Poliquesi 1321 (UEC). Paranaguá, 9/XI/1985, b. fl., Silva s.n. (UEC51679). Pato Branco, 5/XI/1990, b. fl., Ribas \& Giberti 311 (MBM). São José dos Pinhais, 5/XI/1975, b. fl., Hatschbach 34907 (UEC). São Mateus do Sul, 30/X/1985, b. fl., Britez 195 (UEC). Telêmaco Borba, 20/XI/1989, fl., Dias et al. s.n. (FUEL7614). Tijucas do Sul, 2/XI/1989, b. fl., Hatschbach \& Cordeiro 53592 (MBM). Santa Catarina: Penha, 12/XI/1989, b. fl., Silva 670 (MBM).

Distribui-se pelo Brasil (da Bahia a Região Sul) e Paraguai (Giberti 1994). Na Bacia do rio Tibagi ocorre no AT e MT, tanto em vegetações mais abertas quanto no interior de matas de pinhais. Caracterizada pela presença de glândulas punctiformes escuras na face abaxial da folha, I. dumosa foi coletada com flores de setembro a novembro e com frutos em junho, setembro, de novembro a janeiro e em março. É usada como adulterante da erva-mate (Edwin \& Reitz 1967). Esta espécie é frequentemente denominada no Brasil como Ilex amara (Vell.) Loes., que se trata de um homônimo posterior de Ilex amara Bonpl. ex Miers (= Symplocos lanceolata A.DC), e portanto um nome ilegítimo (Groppo \& Pirani 2005).

Ilex paraguariensis A. St.-Hil., Mém. Mus. Hist. Nat. 9: 351. 1822.

Fig. 9

Arvoretas ou árvores, 3-12 m; ramos jovens glabros ou velutinos. Pecíolo glabro ou velutino, sulcado na face adaxial, 5-13 mm; lâmina glabra ou velutina, cartácea a coriácea, 3,5-9,5×2,2-6,2 cm, obovada, elíptica ou menos frequientemente ovada; base aguda a cuneada, às vezes decurrente pelo pecíolo; ápice obtuso; margem crenada principalmente do meio para o ápice, revoluta; nervura primária glabra ou velutina. Inflorescência em dicásios ou fascículos corimbóides; 
pedicelo 4-8 mm; pedúnculo 5-8 mm. Flores 4-meras; sépalas pubescentes, ca. $1 \times 1 \mathrm{~mm}$, triangulares ou ovais, margem não ciliada; pétalas glabras, $2-3 \times 2 \mathrm{~mm}$, elípticas ou obovadas; estames ca. $3 \mathrm{~mm}$, filete $2 \mathrm{~mm}$, antera $1 \mathrm{~mm}$; estaminódios 1-2 mm; ovário subgloboso, 2×2-3 mm, lóbulos inconspícuos, tetralocular; pistilódio subgloboso, rostro não evidente, ca. $1 \mathrm{~mm}$ altura. Fruto globoso, 4-6 mm, violáceo quando maduro, pirenos 4, sulcados dorsalmente.

Material selecionado: BRASIL. Paraná: Apucarana, 2/III/1990, fr., Dias et al. s.n. (FUEL8156). Curiúva, 12/XII/1998, fr., Cavalheiro et al. 29 (FUEL, MBM). Imbituva, 21/X/1986, b. fl., Kuniyoshi \& Galvão 5069 (MBM). Irati, 16/I/1990, fr., Medri et al. s.n. (FUEL8005). Mauá da Serra, 15/ XII/1999, fr., Viani et al. 39 (FUEL). Ortigueira, 17/ X/1999, fl. fr., Viani \& Baitello 34 (FUEL). Palmeira, 22/X/1965, fl., Hatschbach 13054 (MBM). Ponta Grossa, 6/XI/1992, fr., Schiesinsky 150 (FUEL, HUEM). Tamarana, 15/XII/1999, fr., Viani et al. 40 (FUEL). Teixeira Soares, 1/VII/1991, veg., Medri et al. s.n. (FUEL17318). Telêmaco Borba. 16/X/1999, b. fl., Viani \& Baitello 32 (FUEL). Tibagi, 4/V/1990, fl., Bianchini et al. s.n. (FUEL11802, MBM189350). Ventania, 23/II/1999, fr., Pavão et al. s.n. (FUEL24831).

Material adicional: BRASIL. Paraná: Catanduvas, 13/VI/1974, veg., Hatschbach 34517 (UEC). Lapa, 2/XI/1955, b., Braga 34 (UPCB). Curiúva, 24/X/1998, b. fl., Francisco \& Alves s.n. (FUEL22370). São Mateus do Sul, 14/X/1986, b., Britez \& Silva 817 (UEC).

É encontrada no Brasil (Rio de Janeiro, São Paulo, Minas Gerais, Mato Grosso, Mato Grosso do Sul e Região Sul), Uruguai, Argentina, Paraguai e Bolívia (Groppo \& Pirani 2002). Na bacia ocorre preferencialmente no MT e AT. No entanto, coletas de I. paraguariensis no Parque Municipal da Raposa de Apucarana, no BT, indicam que a distribuição desta espécie ocorre do sul até regiões serranas no norte da bacia. Coletada com flores em maio e de setembro a novembro, e com frutos em maio, junho e de outubro a março. I. paraguariensis, a popular erva-mate, é cultivada e explorada comercialmente. Suas folhas são usadas na preparação do chimarrão e de chás, sendo muitas vezes o seu produto adulterado pelas folhas de outras espécies do gênero. Todos os materiais examinados apresentaram folhas glabras, com exceção de um material coletado em Ponta Grossa, com revestimento velutino.
1.1.4. Ilex theezans Mart. ex Reissek, Fl. bras. 11(1): 51.1861.

Fig. 10

Arvoretas ou árvores, 2-9 m; ramos jovens glabros, ocasionalmente com lenticelas. Pecíolo glabro, ocasionalmente em folhas novas com pubescência esparsa, sulcado na face adaxial, 7-15 mm; lâmina glabra, coriácea, quando nova cartácea e enegrecidas, 3,7-10,6×2-4,2 cm; obovadas, elípticas ou oblongas; base aguda e decurrente pelo pecíolo, simétrica; ápice obtuso, mucronado; margem inteira ou com dentes da metade para o ápice, revoluta; nervura primária glabra. Inflorescência em dicásios 3-floros, fascículos corimbóides ou flores solitárias; pedicelo 2-10 mm, pedúnculo 6-9 mm. Flores 4-5-meras; sépalas glabras ou menos freqüente com esparsa pubescência, ca. $1 \times 1 \mathrm{~mm}$, triangulares, margem freqüientemente ciliada; pétalas glabras, 2-5×2 mm, elípticas; estames 2-4 mm, filete 1-3 mm, antera 1-1,5 mm; estaminódios até $2 \mathrm{~mm}$; ovário subgloboso, $2 \mathrm{~mm}$, lóbulos inconspícuos; pistilódio subgloboso, achatado, com mais de $1 \mathrm{~mm}$ de diâmetro e até $1 \mathrm{~mm}$ de altura. Fruto globoso, arroxeado quando maduro, 7-9×4-8 mm; pirenos 5-6, 2-3 mm, cônicos, lisos.

Material selecionado: BRASIL. Paraná: Carambeí, 15/I/1965, fr., Hatschbach et al. 12145 (MBM). Castro, 17/XI/1988, Silva 1631 et al. (MBM). Imbituva, 23/III/1987, fr., Kuniyoshi \& Galvão 5553 (MBM). Ipiranga, 14/XII/1990, fr., Silva et al. s.n. (FUEL9097). Irati, 15/XII/1994, fr., Ziller \& Rachwal 628 (MBM). Mauá da Serra, 1/IX/1999, b. fl., Pavão \& Francisco s.n. (FUEL15743). Ortigueira, 9/VII/1998, fr., Francisco et al. s.n. (FUEL21844). Palmeira, 12/I/1966, fr., G. Hatschbach 13484 (MBM). Ponta Grossa, 10/V/1992, b. fl., Moro s.n. (FUEL31549). Porto Amazonas, 13/X/1963, fl., Hatschbach 11075 (MBM). Reserva, 19/II/1999, fr., Francisco \& Alves s.n. (FUEL23285). São Jerônimo da Serra, 12/XI/1999, fr., Viani et al. 1 (FUEL). Sapopema, 15/X/1998, fl., Francisco et al. s.n. (FUEL22367). Teixeira Soares, 1/VII/1991, veg., Fonseca et al. s.n. (FUEL17322). Telêmaco Borba, 17/X/1999, b. fl., Viani \& Baitello 24 (FUEL). Tibagi, 10/X/1992, fl., Hatschbach \& Barbosa 58205 (FUEL, MBM). Ventania, 9/II/1999, fr., Ferreira et al. s.n. (FUEL24830).

Material adicional: BRASIL. Paraná: Tibagi, 13/IV/1992, b. fl., Moro \& Takeda 913 (FUEL21062). Tijucas do Sul, 2/XI/1989, b. fl., Hatschbach \& Silva 53596 (MBM). 


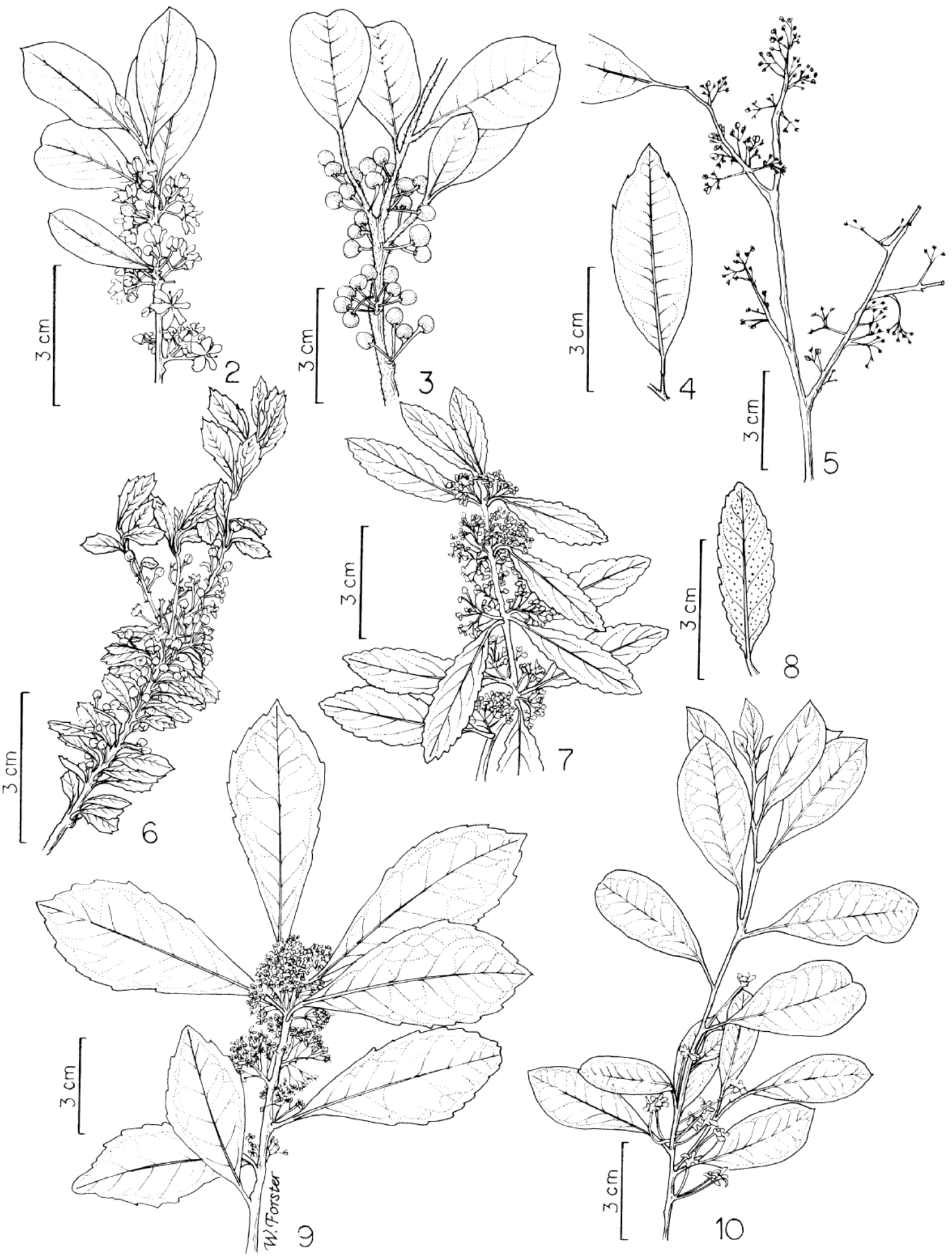

Figuras 2-10. Ilex brasiliensis (Spreng.) Loes.: 2. Ramo com flores (Francisco \& Alves s.n., FUEL21581). 3. Ramo com frutos (Francisco \& Pavão s.n., FUEL24832). Ilex brevicuspis Reissek: 4. Folha (Colli et al. s.n., FUEL7654). 5. Ramos com flores (Colli et al. s.n., FUEL 7654). Ilex chamaedryfolia Reissek: 6. Ramo com botões e flores (Schiesinsky 26). Ilex dumosa Reissek: 7. Ramo com flores (Dias et al. s.n., FUEL7614). 8. Face abaxial da folha (Dias et al. s.n., FUEL7614). Ilex paraguariensis A. St.-Hil.: 9. Ramo com flores (Francisco \& Alves s.n., FUEL22370). Ilex theezans Mart. ex Reissek: 10. Ramo com flores (Moro \& Takeda 913). 
Ocorre no Brasil (Bahia, Goiás, Minas Gerais, Rio de Janeiro, São Paulo e Região Sul), Argentina e Paraguai (Giberti 1994; Groppo \& Pirani 2002). É encontrada principalmente no AT e MT, normalmente em áreas onde também ocorre I. paraguariensis. Coletada com flores de setembro a novembro e com frutos em junho e de outubro a maio. I. theezans assemelha-se muito a I. integerrima (Vell.) Reissek, sendo difícil e não evidente a distinção morfológica entre as duas espécies.

\section{Celastraceae}

Arbustos, arvoretas ou árvores. Folhas alternas, simples, com ou sem estípulas. Inflorescências axilares em cimeiras ou fascículos. Flores monóclinas ou funcionalmente díclinas, diclamídeas, 5-meras ou raramente 6-meras, actinomorfas; gamossépalas; dialipétalas; estames livres, filetes achatados na base, deiscência longitudinal; ovário súpero, imerso ou não no disco carnoso, bicarpelar, placentação axilar. Fruto bilocular ou unilocular por aborto, sâmara ou cápsula loculicida bivalvar; semente com ou sem arilo.

A família Celastraceae é composta por cerca de 50 gêneros e 800 espécies de distribuição tropical e subtropical, sendo que no Brasil ocorrem cinco gêneros (Carvalho-Okano 2005). Na bacia do rio Tibagi foram registrados dois gêneros e sete espécies.

Chave de identificação de gêneros de Celastraceae para a bacia do rio Tibagi

1. Fruto cápsula bivalvar, sementes com arilo, pecíolo 1-10 $\mathrm{mm}$ 2.1. Maytenus

1. Fruto sâmara, sementes sem arilo, pecíolo 20-37 mm. 2.2. Plenckia

\subsection{Maytenus Mol. emend. Mol.}

Arbustos, arvoretas ou árvores. Folhas alternas, simples, com estípulas inconspícuas. Inflorescência axilar em fascículos ou cimeiras. Flores monóclinas, às vezes funcionalmente díclinas; gineceu bicarpelar, bilocular, dois óvulos por lóculo, placentação axilar com óvulos na porção basal, disco carnoso. Cápsula loculicida, bivalvar; sementes com testa rija, lisa, brilhante, castanha ou negra, envoltas totalmente por arilo branco.

O gênero apresenta cerca de 200 espécies pantropicais, com maior concentração na América do Sul (Carvalho-Okano 2005). Na bacia do rio Tibagi foram encontradas seis espécies: $M$. evonymoides Reissek, M. robusta Reissek, M. dasyclada Mart., M. salicifolia Reissek, M. ilicifolia Mart. ex Reissek e M. aquifolia Mart.

Chave de identificação de espécies de Maytenus para a bacia do rio Tibagi

1. Folha com margem serrada com muitos espinhos desde a base

2. Ramos jovens cilíndrico-achatados, não carenados 2.1.1. M. aquifolia

2. Ramos jovens angulosos, carenados 2.1.4. M. ilicifolia

1. Folha com margem inteira, crenada, dentada, dentado-crenada ou dentado-serrada, sem espinhos

3. Ramos jovens cilíndricos ou achatados, inflorescência em cimeiras ramificadas

4. Lâmina foliar coriácea, fruto geralmente piriforme 2.1.5. M. robusta

4. Lâmina foliar membranácea à cartácea, fruto geralmente orbicular 2.1.6. M. salicifolia

3. Ramos jovens carenados, inflorescência em fascículos

5. Fascículos 1-6 floros, lâmina foliar 0,6-1,1 cm de largura 2.1.2. M. dasyclada

5. Fascículos mais que 6-floros, lâmina foliar 1,2-2,5 cm de largura 2.1.3. M. evonymoides

\subsubsection{Maytenus aquifolia Mart., Flora 24(2): 4. 1841.} Fig. 11-12

Arbustos ou árvores, 4,5-15 m; ramos jovens glabros, cilíndrico-achatados. Pecíolo 5-10 mm; lâmina glabra, cartácea, 0,6-1,6×2-5,5 cm, elíptica ou oblongoelíptica; base aguda a obtusa; ápice agudo a obtuso, mucronado; margem com muitos espinhos, serrada; nervura primária proeminente em ambas as faces, secundárias subsalientes. Inflorescência em fascículos 3-15 floros, pedicelo 3-9 mm, bracteolados na base, bractéolas com até $1 \mathrm{~mm}$. Flores com sépalas de $1,5 \mathrm{~mm}$, ovais, subciliadas; pétalas $4 \times 3 \mathrm{~mm}$, ovais; ovário imerso ou não no disco carnoso; estigma séssil ou com estilete distinto. Fruto orbicular, pericarpo maduro castanho-amarelo, 6-10×4-7 mm, estilete persistente; sementes eretas, suborbiculares, elipsóides 
ou obovais, 4-6×3-4 mm, geralmente 2-3 por fruto.

Material selecionado: BRASIL. Paraná: Apucarana, 17/XI/1999, fr., Pavão \& Francisco s.n. (FUEL27325). Arapongas, 9/IX/2000, veg., Viani s.n. (FUEL34890). Bela Vista do Paraíso, 3/X/2000, fr., Ferreira et al. s.n. (FUEL27795). Cornélio Procópio, 25/X/2000, fr., Ferreira s.n. (FUEL30579). Ibiporã, 12/III/1990, veg., Chagas e Silva et al. (FUEL12121). Leópolis, 26/X/1999, fr., Pavão \& Ferreira s.n. (FUEL27329). Londrina: 9/XII/1993, fr., Chagas e Silva 1673 (FUEL). Ortigueira, 11/IX/1998, fr., Francisco et al. s.n. (FUEL21855). São Jerônimo da Serra, 21/VIII/1999, fl., Teixeira s.n. (FUEL26025). Santo Antônio do Paraíso, 12/XI/1999, fr., Francisco \& Pavão s.n. (FUEL27330). Sapopema, 29/VIII/1998, fl., Medri et al. s.n. (FUEL22688, MBM241722). Telêmaco Borba, 17/VIII/1990, veg., Silva et al. s.n. (FUEL12434). Tibagi, 11/VIII/1994, veg., Vieira et al. s.n. (FUEL11712).

Material adicional: BRASIL. Paraná: Londrina, 27/VIII/1993, b. fl., Soares-Silva 327 (FUEL); 27/X/1994, fr., Chagas e Silva 1772 (FUEL). São Paulo: Botucatu, 4/XI/1988, fl., Gabriel s.n. (FUEL210680). Brotas, 19/X/1989, fr., Salis 1 (FUEL).

Maytenus aquifolia é encontrada em Minas Gerais, Rio de Janeiro e São Paulo e toda Região Sul do Brasil (Carvalho-Okano \& Leitão Filho 2004). Na bacia do Tibagi ocorre preferencialmente no BT e MT, onde foi coletada com flores em agosto e dezembro e com frutos de agosto a dezembro. M. aquifolia é freqüentemente confundida com $M$. ilicifolia, porém distingue-se desta por seus ramos cilíndrico-achatados (Carvalho-Okano \& Leitão Filho 2004) e por suas folhas geralmente com dimensões maiores. Conhecida vulgarmente pelo nome de espinheira-santa, é cultivada e utilizada na medicina popular.

2.1.2. Maytenus dasyclada Mart., Flora 24(2): 89. 1841.

Fig. 13-14

Arbustos ou arvoretas, 1,0-2,5 m; ramos jovens pubescentes, muito ramificados no ápice, tetracarenados. Pecíolo 1-3 mm; lâmina glabra, membranácea, 1,5-2,7×0,6-1,1 cm, elíptica ou oboval; base atenuada ou cuneada; ápice agudo, obtuso ou emarginado; margem dentado-crenada; nervura primária saliente em ambas as faces, secundárias evidentes, subsalientes na face abaxial. Inflorescência em fascículos congestos com 1-6 flores; pedicelo 3-6 $\mathrm{mm}$, bracteolados na base, bractéolas fimbriadas com até $1 \mathrm{~mm}$. Flores com sépalas de $1 \mathrm{~mm}$, semicirculares, ciliadas; pétalas $2 \times 2 \mathrm{~mm}$, suborbiculares, fimbriadas; ovário parcialmente coberto pelo disco carnoso; estigma capitado, subséssil. Fruto orbicular, pericarpo maduro alaranjado, 5-8×5-8 mm; sementes eretas suborbiculares, elipsóides ou obovais, 3-5 $\times 2-4 \mathrm{~mm}$, geralmente 2-3 por fruto.

Material selecionado: BRASIL. Paraná: Londrina, 1/XI/1996, fr., Crepaldi et al. s.n. (FUEL3866). Cambé, 10/XI/1997, b. fl., Kinupp et al. 613 (FUEL).

Material adicional: BRASIL. Paraná: Cambé, 16/VII/1998, b. fl., Francisco s.n. (FUEL21648). Palmas, 9/VIII/1990, Silva \& Ravsches 863 (MBM).

Maytenus dasyclada ocorre no Uruguai e no Brasil, do Rio Grande do Sul até São Paulo e Rio de Janeiro (Carvalho-Okano \& Leitão Filho 2004). Na bacia do rio Tibagi foi encontrada em apenas duas localidades, em municípios do BT, sendo coletada com flores em julho e novembro, e com frutos em julho, agosto, outubro e novembro. É identificada por suas folhas pequenas e membranáceas e por seus ramos carenados. Espécie próxima de M. glaucescens Reissek, porém esta última não foi encontrada na bacia do rio Tibagi e apresenta folhas coriáceas e acinzentadas. M. dasyclada difere de M. evonymoides pelas folhas menores e membranáceas e por seus indivíduos (arvoretas) de menor altura.

2.1.3. Maytenus evonymoides Reissek, Fl. bras. 11(1): 11. 1861.

Fig. 15

Arbustos ou árvores, 3-6,5 m; ramos jovens pubérulos ou densamente pilosos, angulosos. Pecíolo 1-5 mm; lâmina glabra, membranácea a cartácea, $3-7 \times 1,2-2,5 \mathrm{~cm}$, elíptica ou mais comumente estreitamente elíptica; base atenuada ou cuneada; ápice agudo ou obtuso; margem dentado-crenada; nervura primária saliente em ambas as faces, secundárias subsalientes na face abaxial. Inflorescência em fascículos com mais de seis flores; pedicelos 2-4 mm, bracteolados na base, bractéolas fimbriadas com até $1 \mathrm{~mm}$. Flores com sépalas de $1,5 \mathrm{~mm}$, ovais; pétalas $2 \times 1,5 \mathrm{~mm}$, obovais, fimbriadas; ovário parcialmente coberto ou imerso pelo disco carnoso; estigma capitado, subséssil. Fruto orbicular, pericarpo maduro amarelo, 5-8 $\times 4-8 \mathrm{~mm}$; sementes eretas suborbiculares, elipsóides ou obovais, 4-6×2-4 mm, geralmente 2-3 por fruto.

Material selecionado: BRASIL. Paraná: Imbaú, 13/XII/1996, fr., Kinupp et al. 88 (FUEL). Ipiranga, 29/VII/1998, b. fl., Souza et al. s.n. (FUEL21846). 
Piraí do Sul, 21/VII/1998, b., Souza et al. s.n. (FUEL21854, MBM230745). Ponta Grossa, 29/X/1995, fr., Silva et al. s.n. (FUEL17282). Reserva, 11/XI/1998, fr., Francisco \& Alves s.n. (FUEL22663). São Jerônimo da Serra: 21/VIII/1998, b. fl., Souza et al. s.n. (FUEL21847). Telêmaco Borba, 17/X/1999, fr., Viani \& Baitello 31 (FUEL). Tibagi, 12/XII/1989, fr., Vieira et al. 383 (FUEL). Ventania, 5/VII/1998, b., Paiva et al. s.n. (FUEL21927).

Material adicional: BRASIL. Paraná: Jaguariaíva, 4/XII/1988, fr., Vieira et al. 247 (FUEL). Paranaguá, 20/XII/87, b., Britez 1826 (FUEL). São Paulo: Apiaí, 13/XII/1997, fr., Torezan et al. 630 (FUEL). Bom Sucesso do Itararé, 11/XII/1997, fr., Elias et al. 71 (FUEL).

Amplamente distribuída nas Regiões Sul, Sudeste e Centro-Oeste do Brasil (Carvalho-Okano \& Leitão Filho 2004), M. evonymoides ocorre no AT e MT, sendo a espécie do gênero encontrada com maior frequiência na bacia. Coletada com flores em julho e agosto, e com frutos em agosto, de outubro a dezembro e em fevereiro e maio. É reconhecida por seus ramos angulosos, folhas com margem crenada e inflorescências em fascículos. Carvalho-Okano \& Leitão Filho (2004) citam para M. evonymoides folhas membranáceas como característica para identificação da espécie, porém indivíduos coletados na bacia apresentaram textura foliar variando de membranácea a cartácea.

2.1.4. Maytenus ilicifolia Mart. ex Reissek, Fl. bras. 11(1): 8. 1861 .

Fig. 16

Arbustos ou árvores, 2-5 m; ramos jovens glabros, angulosos, tetra ou multi-carenados. Pecíolo de 2-6 mm; lâmina glabra, coriácea, 4-10×1,8-3,5 cm, elíptica ou estreitamente elíptica; base aguda a obtusa; ápice agudo a obtuso, mucronado ou aristado; margem com vários espinhos distribuídos regularmente ou não na borda; nervura primária e secundária proeminentes. Inflorescência em fascículos multifloros; pedicelos de 2-6 mm, bractéolas na base. Flores com sépalas de $1 \mathrm{~mm}$, semicirculares, ciliadas; pétalas $2,2 \times 2 \mathrm{~mm}$, ovais; ovário imerso ou não no disco carnoso; estigma capitado, séssil ou com estilete distinto. Fruto orbicular, pericarpo maduro vermelho-laranja, 5-6×4-5 mm; sementes eretas, suborbiculares, elipsóides ou obovais, 3-4×2-3 mm, geralmente 2-3 por fruto.

Material selecionado: BRASIL. Paraná: Ivaí, 30/XII/1998, b. fl., Souza et al. s.n. (FUEL21881, MBM230744). Piraí do Sul, 17/XI/1970, fr.,
Hatschbach \& Guimarães 25414 (FUEL, MBM). Teixeira Soares, 5/XII/1996, fr., Souza \& Mendes s.n. (FUEL20116).

Material adicional: BRASIL. Paraná: Curitiba, 19/XII/1977, fr., Hatschbach 40316 (UEC). São Mateus do Sul, 13/X/1986, fr., Britez \& Silva s.n. (UEC63800). São Paulo: Flórida Paulista, 16/XI/1936, fr., Coletti s.n. (FUEL4137).

Ocorre principalmente na Região Sul do Brasil, Paraguai, Bolívia e leste da Argentina, podendo ser encontrada também no Chile e Uruguai (CarvalhoOkano \& Leitão Filho 2004). Na bacia está restrita aos remanescentes de Floresta Ombrófila Mista do AT. É atualmente considerada espécie rara no estado do Paraná, por apresentar uma população sensivelmente reduzida (SEMA 1995). M. ilicifolia foi coletada com flores em julho e com frutos em novembro e dezembro. Freqüentemente é confundida com M. aquifolia, distinguindo-se desta por seus ramos angulosos e carenados (Carvalho-Okano \& Leitão Filho 2004) e suas folhas geralmente menores. Conhecida vulgarmente como espinheira-santa, M. ilicifolia tem suas folhas empregadas na medicina popular (Mattos 1965).

2.1.5. Maytenus robusta Reissek, Fl. bras. 11(1): 15. 1861.

\section{Fig. 17}

Arbustos ou árvores, 3-13 m; ramos jovens glabros, cilíndricos. Pecíolo 3-6 mm; lâmina coriácea, 5,2-9,5×2,1-4,3 cm, elíptica, lanceolada, oblongo-ovada; base cuneada a obtusa; ápice agudo, acuminado; margem subrevoluta, crenada ou dentada; nervura primária saliente em ambas as faces, secundárias salientes na face abaxial. Inflorescência em cimeiras, subsésseis ou pedunculadas, laxa, ramificada, multifloras; pedicelos de 4-5 $\mathrm{mm}$, bracteoladas na base, bractéolas fimbriadas com até $1 \mathrm{~mm}$. Flores com sépalas de $1 \mathrm{~mm}$, obtusas, subciliadas; pétalas 1-2 mm, obovais; estames situados externamente à porção basal do disco; ovário saliente ou imerso no disco; estigma capitado, subséssil. Fruto piriforme, menos frequentemente suborbicular, pericarpo maduro amarelo, 8-12×7-8 mm; sementes eretas, suborbiculares, elipsóides ou obovais, 7-9×3-6 mm, geralmente 2-3 por fruto.

Material selecionado: BRASIL. Paraná: Palmeira, 26/X/1982, Hatschbach 45732 (MBM). Piraí do Sul, 14/VI/1973, Hatschbach 32150 (MBM). Ponta Grossa, 15/V1989, fr., Cervi et al. 2693 (MBM). Tibagi, 11/XII/1989, fr., Dias et al. s.n. (FUEL7819). 
Material adicional: BRASIL. Paraná: Jaguariaíva, 13/XII/1977, fr., Uhlmann \& Mendonça 75 (UEC). Matinhos, 19/IX/1946, b. fl., Hatschbach 259 (FUEL). Paranaguá, 1/XI/1986, fr., Souza \&. Silva 333 (FUEL). Tibagi, 10/II/1997, fr., Kinupp 266 (FUEL).

Ocorre na vegetação de restinga dos estados de Santa Catarina, Paraná, São Paulo e menos freqüentemente Rio de Janeiro, penetrando no interior de matas dos estados de São Paulo, Minas Gerais, Goiás (Carvalho-Okano \& Leitão Filho 2004). Não existia registro para o interior do Paraná, entretanto foi encontrada no AT e principalmente no MT. Maytenus robusta foi coletada com flores em setembro e outubro, e com frutos em fevereiro, maio, junho e de outubro a dezembro. Caracterizada pelos ramos cilíndricos, frutos geralmente piriformes e folhas de margem crenada ou dentada, frequientemente com coloração acinzentada no material herborizado. Muitos dos materiais examinados apresentavam galhas nas folhas e estavam identificados como $M$. alaternoides, que é sinônimo de M. robusta (Carvalho-Okano 1998).

2.1.6. Maytenus salicifolia Reissek, Fl. bras. 11(1): 10. 1861.

Fig. 18-19

Árvores 2,5-12 m; ramos novos achatados, glabros. Pecíolo 2-5 mm; lâmina glabra, membranácea a cartácea, 4,9-11,4×1,6-3,9 cm, estreitamente elíptica, lanceolada ou elíptica; base cuneada a obtusa; ápice acuminado ou agudo; margem dentado-serrada. Inflorescência em cimeiras axilares, densas e ramificadas; pedicelos de 2-3 $\mathrm{mm}$, bracteolados na base; sépalas $1 \mathrm{~mm}$, ciliadas, obtusas; pétalas 1-2 mm, ovais ou elípticas; estames curvos, voltados para o centro; ovário total ou parcialmente imerso no disco; estigma capitado, séssil. Fruto orbicular ou suborbicular, pericarpo madurao amarelo, 7-11×5-7 mm; estigma persistente; pedicelo 3-4 mm; sementes geralmente duas por fruto.

Material selecionado: BRASIL. Paraná: Ibiporã, 4/V/1999, fr., Vieira et al. s.n. (FUEL24895). Curiúva, 16/X/1999, b. fl., Viani \& Baitello 35 (FUEL). Reserva, 13/XII/1996, veg., V.F. Kinupp et al. 90 (FUEL). São Jerônimo da Serra, 5/VIII/1999, fr., Viani et al. 9 (FUEL). Sapopema: 15/X/1998, fl., Viani et al. 3 (FUEL). Ventania, 25/I/2001, fr., Fadelli et al. 328 (ESA, FUEL).

Material adicional: BRASIL. Minas Gerais: Poços de Caldas, 14/X/1981, b., Tamashiro et al. s.n. (FUEL13990). Paraná: Ibaiti, 17/X/1997, Hatschbach et al. 67152 (MBM). Sapopema: 2/III/1999, fr.,
Francisco s.n. (FUEL24893). Ventania, 23/X/1998, b., fl., Francisco \& Alves s.n. (FUEL24890, MBM239687).

Maytenus salicifolia ocorre em Minas Gerais, São Paulo e Rio de Janeiro, sendo geralmente encontrada em matas do interior, não sendo citada para o Paraná até a última revisão do gênero (ver Carvalho-Okano \& Leitão Filho 2004), demonstrando a importância de coletas regionalizadas para o completo conhecimento da distribuição geográfica das espécies. $\mathrm{Na}$ bacia do rio Tibagi ocorre no BT e principalmente MT, onde é encontrada com freqüência. Coletada com flores em outubro e com frutos em outubro, de dezembro a fevereiro, em maio e julho. $M$. salicifolia é muito semelhante a $M$. robusta, diferenciando-se pelas folhas de ápice freqüentemente acuminado e textura membranácea a cartácea, pela inflorescência mais densa e pelo fruto geralmente orbicular. Embora haja semelhança no formato da folha entre as duas espécies, em $M$. salicifolia predomina a forma lanceolada, enquanto em $M$. robusta predomina a elíptica.

2.2. Plenckia populnea Reissek, Fl. bras. 11(1): 31, t. 5, 10, f. 3-5. 1861.

Fig. 20-21

Arbustos a árvores, 2,5-6 m; ramos jovens glabros, cilíndricos, freqüentemente lenticelados. Folhas alternas, glabras, simples, sem estípulas; pecíolo 20-37 mm; lâmina cartácea a coriácea, 2,7-7,4×2-5 cm, oval, ovada ou oblongo ovada; base obtusa, simétrica; ápice acuminado; margem dentada ou crenada; nervura primária proeminente em ambas as faces. Inflorescência axilar, cimeiras laxas; pedicelo de 1-3 mm. Flores hermafroditas, sépalas 1-1 mm, ovais ou obovais; pétalas $5-6,3 \times 2 \mathrm{~mm}$, elípticas ou ovais. Fruto sâmara, obovado-lanceolada, amarela, unilocular por aborto, indeiscente, 21-26x 2-8 mm; uma semente por fruto, presa na porção basal do eixo, sem arilo.

Material selecionado BRASIL. Paraná: São Jerônimo da Serra, 28/X/1999, b. fl., Mendonça et al. 24 (FUEL). Ponta Grossa, 24/XI/1999, b. fl., Cordeiro \& Barbosa 609 (ESA, MBM). Tibagi, 16/VI/1992, fr., Takeda 500 (FUEL). Ventania, 8/VI/2005, veg., Estevan et al. 732 (FUEL).

Material adicional: BRASIL. Goiás: Alto Paraíso, 15/X/1990, fl., Hatschbach 1990 (FUEL). Minas Gerais: Poços de Caldas, 2/XII/1982, fl. fr., Leitão Filho et al. s.n. (FUEL13829). Paraná: Tibagi, 8/X/1988, b. fl., Pinheiro et al. 35 (FUEL). São Paulo: Itapeva, 17/XII/1997, b. fl., Torezan 742 (FUEL). 


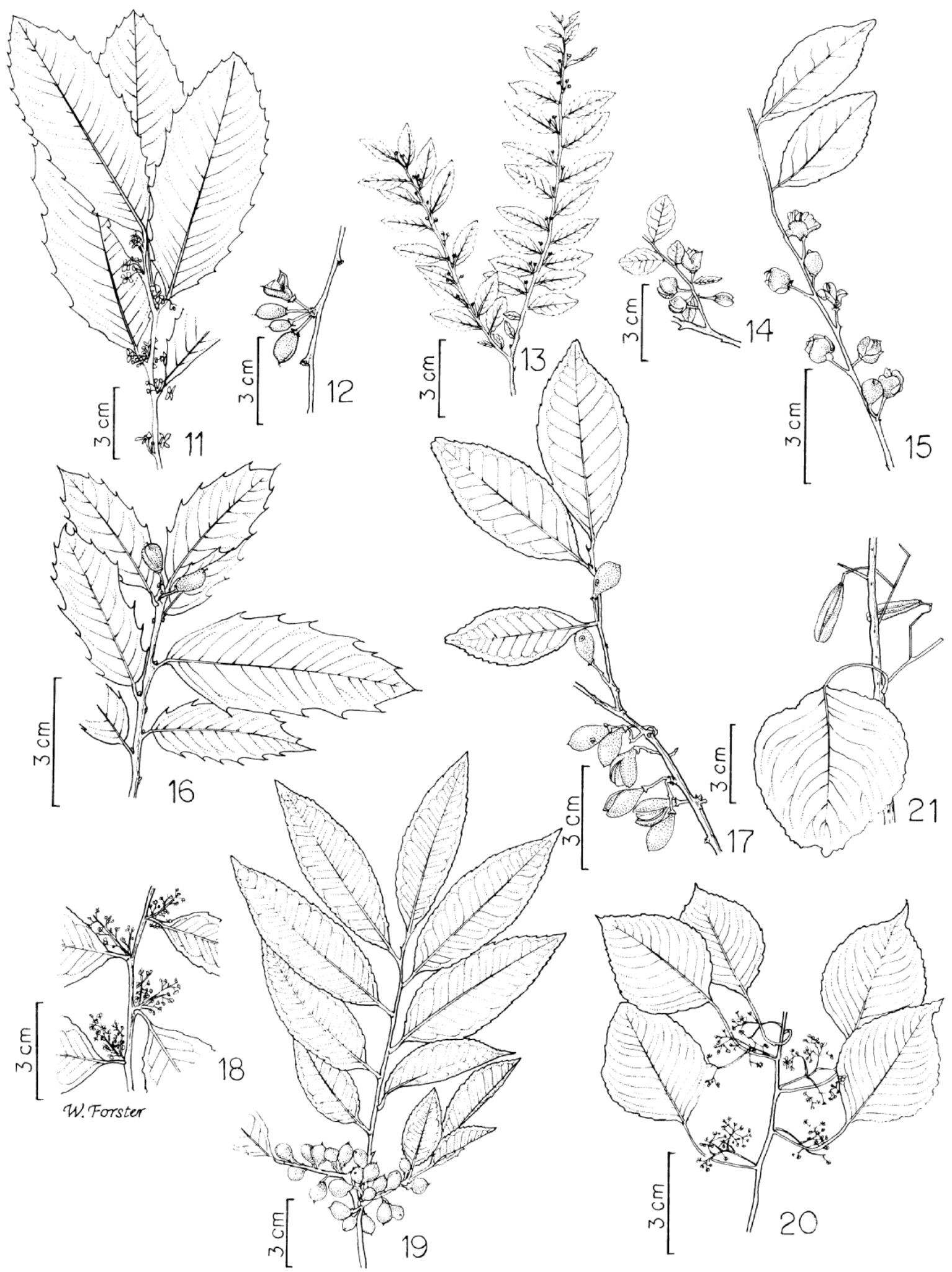

Figuras 11-21. Maytenus aquifolia Mart.: 11. Ramo com flores (Soares-Silva 327). 12. Frutos (Chagas e Silva 1772). Maytenus dasyclada Mart.: 13. Ramo com flores (Francisco s.n., FUEL21648). 14. Frutos (Kinupp et al. 613). Maytenus evonymoides Reissek: 15. Ramo com frutos (Silva et al. s.n., FUEL17282). Maytenus ilicifolia Mart. ex Reissek: 16. Ramo com frutos (Souza \& Mendes s.n., FUEL20116). Maytenus robusta Reissek: 17. Ramos com frutos (Kinupp 266). Maytenus. salicifolia Reissek: 18. Inflorescências (Francisco \& Alves s.n., FUEL24890). 19. Ramo com frutos (Francisco s.n., FUEL24893). Plenckia populnea Reissek: 20. Ramo com flores (Pinheiro et al. 35). 21. Ramo com frutos (Takeda 500). 
Ocorre no Paraguai e no Brasil, sendo encontrada em São Paulo, Minas Gerais, Goiás (Lorenzi 1992) e Bahia (Carvalho-Okano 1995). Na bacia do rio Tibagi foi encontrada em fragmentos remanescentes de cerrado e em campos naturais, no MT e BT, florescendo de setembro a dezembro, e frutificando em junho e dezembro. $P$. populnea é espécie única no gênero, sendo caracterizada pelos longos pecíolos e frutos tipo sâmaras.

\section{Icacinaceae}

Compreende cerca de 60 gêneros e aproximadamente 450 espécies pantropicais (Barroso et al. 1991). No Brasil ocorrem dez gêneros (Mazine et al. 2005). Na bacia do rio Tibagi foi registrado apenas o gênero Citronella.

\subsection{Citronella D. Don}

Árvores; ramos jovens glabros, cilíndricos, estriados longitudinalmente, lenticelados. Folhas alternas, simples, sem estípulas; pecíolo glabro, sulcado na face adaxial; lâmina coriácea, com domácias urceoladas nas axilas das nervuras da face abaxial, margem cartilaginosa; nervura proeminente na face abaxial. Inflorescência paniculada, axilar ou terminal. Flores hermafroditas, diclamídeas, actinomorfas; sépalas 5, gamossépalas, ovais; pétalas 5, imbricadas, livres, glabras, elípticas, com saliência nerviforme crassa, isostêmones, estames menores que a corola, alternos às pétalas, filetes eretos, com base larga, até três vezes maiores que a antera, antera basifixa, deiscência longitudinal; ovário súpero, sincárpico, 1-locular, incompletamente septado, 2-ovular, óvulos pendentes, estilete excêntrico; estigma capitado. Fruto drupáceo, glabro, com falso septo persistente, endocarpo lenhoso; sementes 1.

O gênero Citronella conta com cerca de 20 espécies, com ocorrência nas Américas Central e do Sul, Oceania, Índia e Filipinas (Mazine et al. 2005). $\mathrm{Na}$ bacia do rio Tibagi é representado por duas espécies, C. gongonha e C. paniculata.

Chave de identificação para espécies de Citronella para a bacia do rio Tibagi

1. Lâmina foliar com ápice mucronado, margem inteira ou dentada, freqüentemente aculeada, ovário glabro

\subsubsection{Citronella gongonha}

1. Lâmina foliar sem ápice mucronado, margem inteira, não aculeada, ovário hirsuto 3.1.2. C. paniculata
3.1.1. Citronella gongonha (Mart.) R.A. Howard, J. Arnold Arb. 21: 471. 1940.

Fig. 22-23

Árvores, ca. $4 \mathrm{~m}$; ramos jovens fistulosos. Pecíolo 6-11 mm; lâmina 3,7-9,6×2,5-4,9 cm, face adaxial glabra, face abaxial pubescente, tricomas adpressos castanhos ou esbranquiçados, elíptica ou levemente obovada; base obtusa ou levemente atenuada; ápice agudo a obtuso, mucronado; margem inteira ou dentada, freqüentemente aculeada. Inflorescência 22-41 mm compr., eixo pubescente. Flores com sépalas pubescentes, ca. $1 \mathrm{~mm}$, cremes a castanhas, tricomas hirsutos; pétalas glabras, 2-3×1-2 mm, cremes; estames 1-3 mm; ovário glabro. Fruto ovóide, obovóide ou elipsóide, roxo-escuro quando maduro, $13 \times 8 \mathrm{~mm}$.

Material selecionado: BRASIL. Paraná: Ipiranga, 29/VII/1998, b. fl., Souza et al. s.n. (FUEL22111, HUEM5327, MBM239639). Nova Santa Bárbara, 11/VI/1999, b., Ferreira et al. s.n. (FUEL24892). Tamarana, 22/IX/1998, fr., Francisco \& Alves s.n. (FUEL22664).

Material adicional: BRASIL. Paraná: Campo Largo, 9/IX/1986, fl., Kummrow et al. 2801 (FUEL). Contenda, 17/IX/1981, b. fl., Kummrow 1571 (UEC). Curitiba, 19/X/1995, fr., Carrião et al. s.n. (FUEL22325). São José dos Pinhais, 4/IX/1986, b. fl., Cordeiro \& Silva 358 (UEC). São Paulo: Bom Sucesso do Itararé, 13/XII/1997, fr., Torezan et al. 628 (FUEL).

Ocorre no Uruguai, Paraguai e Argentina (Duno de Stefano 2002) e no Brasil, de Mato Grosso e Minas Gerais até o Rio Grande do Sul. Na bacia foi encontrada no AT e BT, ocorrendo preferencialmente em áreas úmidas ou paludosas. Coletada com flores em julho e com frutos em setembro e dezembro. C. gongonha é caracterizada pelas folhas com ápice mucronado e margem aculeada e pelo ovário glabro.

3.1.2. Citronella paniculata (Mart.) R.A.Howard, J. Arnold Arb. 21: 473. 1940.

Fig. 24-25

Árvores, 3-18 m; ramos jovens estriados, freqüentemente fistulosos. Pecíolo 6-16 mm; lâmina 7,5-16,3×2,2-7,6 cm, glabra, elíptica; base atenuada ou levemente obtusa; ápice agudo a obtuso, raramente acuminado; margem inteira. Inflorescência 18-52 mm compr., eixo piloso. Flores com sépalas hirsutas, $1 \times 0,5 \mathrm{~mm}$, branco-amareladas, tricomas esbranquiçados; pétalas glabras a esparsamente pubescentes, 3×1-2 mm, amareladas; estames 2-3 mm; ovário 
hirsuto. Fruto ovóide, arroxeado quando maduro, $13-15 \times 10-12 \mathrm{~mm}$.

Material selecionado: BRASIL. Paraná: Congoinhas, 9/XII/1997, fr., Souza et al. s.n. (FUEL21215). Curiúva, 24/XI/1999, fr., Cavalheiro
155 (FUEL). Irati, 29/IX/1972, fl., Carvalho 27 (MBM, UPCB). Londrina, 27/VIII/1993, fl., SoaresSilva \& Chagas e Silva 325 (FUEL). Ortigueira, 11/X/1998, fr., Francisco et al. s.n. (FUEL21843). Primeiro de Maio, 17/VIII/1999, fr., Pavão et al. s.n.
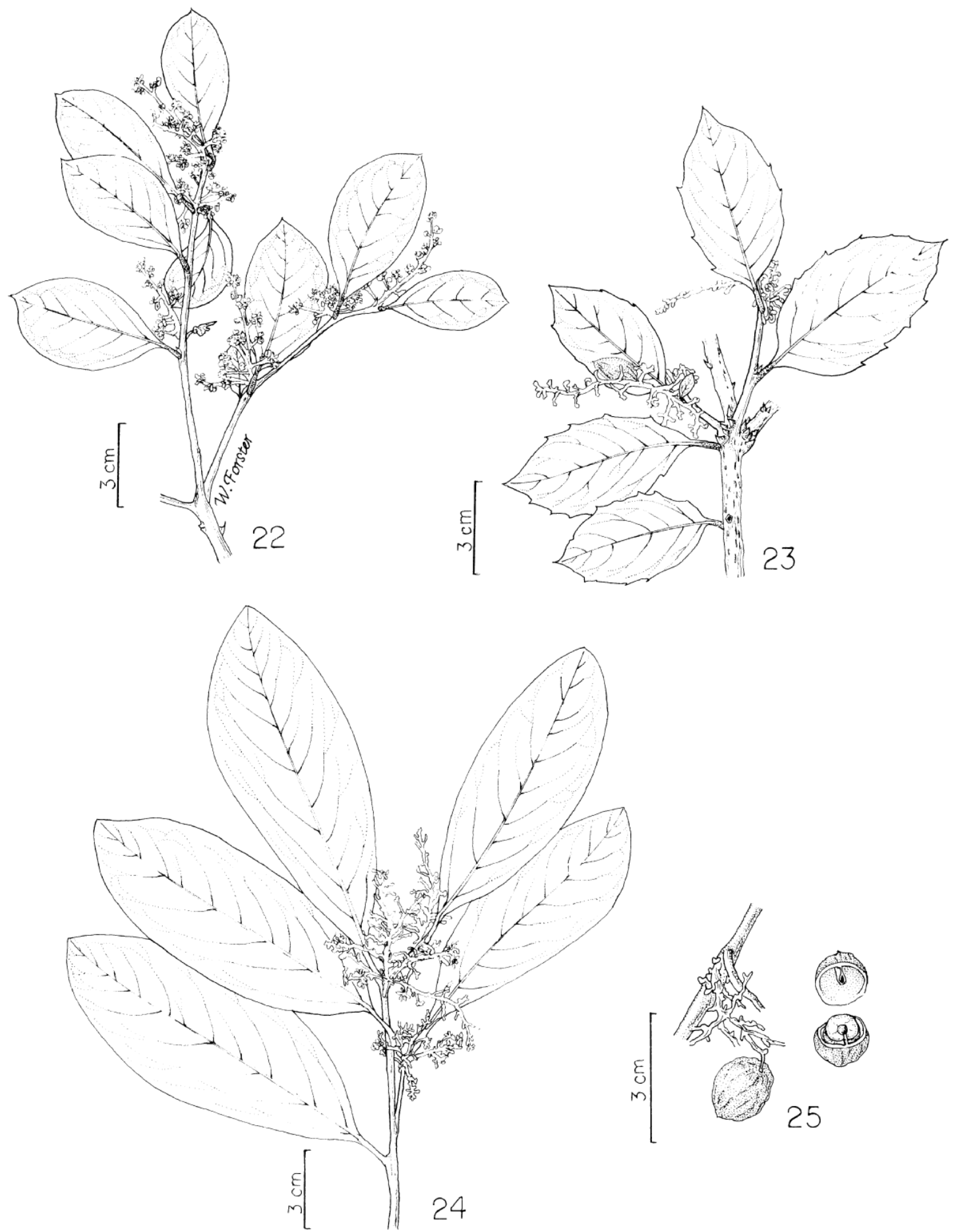

Figuras 22-25. Citronella gongonha (Mart.) R.A.Howard: 22. Ramo com flores (Souza et al. s.n., FUEL22111). 23. Ramo com frutos. (Francisco \& Alves s.n., FUEL22664). Citronella paniculata (Mart.) R.A.Howard: 24. Ramo com flores (Soares-Silva \& Chagas e Silva 325). 25. Frutos (Souza et al. s.n., FUEL21215). 
(FUEL25545). Telêmaco Borba, 10/XI/1995, veg., Dias et al. s.n. (FUEL18137). Tibagi, 11/VII/1998, veg., Vieira et al. s.n. (FUEL11701).

Material adicional: BRASIL. Paraná: Paranaguá, 26/III/1988, b. fl., Souza \& et al. 1261 (FUEL).

Ocorre no Brasil, de Minas Gerais até o Rio Grande do Sul, Paraguai e Argentina (Howard 1942; Duno de Stefano 2002). Na bacia foi coletada no BT e MT, ocorrendo preferencialmente no interior das Florestas Estacional Semidecidual e Ombrófila Mista. Flores foram encontradas em agosto e setembro, e frutos em agosto e de outubro a dezembro. C. paniculata apresenta folhas sem espinhos e geralmente maiores que as de $C$. gongonha, facilitando a distinção entre as duas espécies.

\section{Agradecimentos}

Ao CNPq, Conselho Nacional de Desenvolvimento Científico e Tecnológico, pelas bolsas (CNPq/ RHAE) de iniciação científica, concedida a Ricardo Augusto Gorne Viani e de estágio no país, concedida a Ana Odete Santos Vieira; ao Wellington Forster, pelas ilustrações botânicas.

\section{Referências bibliográficas}

APG - The Angiosperm Phylogeny Group 2003. An update of the angiosperm phylogeny group classification for the orders and families of flowering plants: APG II. Botanical Journal of the Linnean Society 141: 399-436.

Barroso, G.M.; Peixoto, A.L.; Costa, C.G.; Ichaso, C.L.F.; Guimarães, E.F. \& Lima, H.C. 1991. Sistemática de angiospermas do Brasil, v.2, Viçosa, Impr. Univ. UFV.

Carvalho-Okano, R.M. 1995. Celastraceae. Pp. 171-172. In: B.L. Stannard (ed.). Flora of the Pico das Almas, Chapada da Diamantina - Bahia, Brazil. Kew, Royal Botanic Garden.

Carvalho-Okano, R.M. 1998. Novos sinônimos para espécies de Maytenus Mol. Emend. Mol. (Celastraceae). Bradea 8(14): 73-76.

Carvalho-Okano, R.M. \& Leitão Filho, H.F. 2004. O gênero Maytenus Mol. emend. Mol. (Celastraceae) no Brasil extra-amazônico. Pp.11-51. In: M.S. Reis \& S.R. Silva (eds.). Conservação e uso sustentável de plantas medicinais e aromáticas: Maytenus spp., espinheira santa. Brasília, Ibama.

Carvalho-Okano 2005. Celastraceae. Pp. 185-194. In: M.G.L. Wanderley; G.L. Shepherd; T.S. Melhem; S.E. Martins; M. Kirizawa \& A.M. Giulietti, Flora Fanerogâmica do Estado de São Paulo, v.4, São Paulo, FAPESP: Rima.
Cronquist, A. 1988. The evolution and classification of flowering plants. 2 ed. New York, The New York Botanical Garden.

Dias, M.C.; Vieira, A.O.S. \& Paiva, M.R.C. 2002. Florística e fitossociologia das espécies arbóreas das florestas da bacia do rio Tibagi. Pp. 109-124. In: M.E. Medri; E. Bianchini; O.A. Shibatta \& J.A. Pimenta (eds.). A Bacia do Rio Tibagi, Londrina.

Duno de Stefano, R. 2002. Icacinaceae. Pp. 1-21. In: R. Spichiger \& L. Ramella (eds.). Flora del Paraguay. v.37, Saint-Louis, Editions des la Ville de Genève, Chambèsy; Missouri Botanical Garden.

Edwin, G. \& Reitz, P.R. 1967. Aquifoliaceae. Pp.1-47. In: P.R. Reitz (ed.). Flora Ilustrada Catarinense. Parte I, fasc. Aqui. Itajaí, Herbário Barbosa Rodrigues.

Fundação SOS Mata Atlântica \& Instituto Nacional de Pesquisas Espaciais (INPE). 2002. Atlas dos remanescentes florestais e ecossistemas associados do domínio da mata atlântica no período 1995-2000. São Paulo.

Giberti, G.C. 1994. Aquifoliaceae. Pp.1-34. In: R. Spichiger \& L. Ramella (eds.). Flora del Paraguay. v.24, Saint-Louis, Editions des la Ville de Genève, Chambèsy; Missouri Botanical Garden.

Groppo, M. \& Pirani, J.R. 2002. Aquifoliaceae. Pp. 31-38. In: M.G.L. Wanderley; G.L. Shepherd \& A.M. Giulietti (eds.). Flora Fanerogâmica do Estado de São Paulo. v.2, São Paulo, FAPESP: HUCITEC.

Groppo, M. \& Pirani, J.R. 2005. Flora da Serra do Cipó, Minas Gerais: Aquifoliaceae. Boletim de Botânica da Universidade de São Paulo 23(2): 257-265.

Horward, R.A. 1942. Studies of the Icacinaceae V: A revision of the genus Citronella D. Don. Contributions from the Gray Herbarium of Harvard University 142: 60-92.

Holmgren, P.K. \& Holmgren, N. H. 2005. Index Herbariorum. The New York Botanical Garden. Disponível em http:// sciweb.nybg.org/science2/IndexHerbariorum.asp, (Acesso em: 22/11/2005).

Loesener, T. 1942a. Aquifoliaceae. Pp.37-86. In: A. Engler \& K. Prantl (eds.). Die Naturlichen Planzenfamilien 2 ed. v.20b.

Loesener, T. 1942b. Celastraceae. Pp. 135-146. In: A. Engler \& K. Prantl (eds.). Die Naturlichen Planzenfamilien 2 ed. v. $20 b$.

Lorenzi, H. 1992. Árvores brasileiras: manual de identificação e cultivo de plantas arbóreas nativas do Brasil. v.1. Nova Odessa, Editora Plantarum.

Macedo, I.C.C. \& Chiea, S.C. 1986. Aquifoliaceae In: Flora Fanerogâmica da Reserva do Parque Estadual das Fontes do Ipiranga. Hoehnea 13: 141-143.

Mattos, J.R. 1965. Flora do Rio Grande do Sul. v.7. São Paulo, Instituto de Botânica.

Mazine F.F.; Souza, V.C. \& Rodrigues, R.R. 2005. Icacinaceae. Pp. 227-229. In: M.G.L. Wanderley; G.L. Shepherd; T.S. Melhem; S.E. Martins; M. Kirizawa \& A.M. Giulietti, Flora Fanerogâmica do Estado de São Paulo. v.4. São Paulo, FAPESP: Rima.

Medri, M.E.; Bianchini, E.; Shibatta, O.A. \& Pimenta, J.A. (eds.). 2002. A bacia do rio Tibagi. Londrina. 
Reissek, S. 1861. Celastrinae; Ilicineae; Rhamneae. Pp. 1-79 In: C.P.F. Martius \& A.G. Eichler (eds.). Flora Brasiliensis. Monachii, Typographia Regia v.11, pars.1. SEMA, 1995. Lista vermelha de plantas ameaçadas de extinção no Estado do Paraná. Curitiba, Secretaria de Estado do Meio Ambiente/GTZ.

Sleumer, H. 1942. Icacinaceae. Pp.322-396 In: A. Engler \& K. Prantl, (eds.). Die Naturlichen Planzenfamilien 2 ed. v.20b.
Souza, V.C. \& Lorenzi, H. 2005. Botânica sistemática: guia ilustrado para identificação das famílias de angiospermas da flora brasileira, baseado em APG II. Nova Odessa, Instituto Plantarum.

Torezan, J.M.D. 2002. Nota sobre a vegetação do rio Tibagi. Pp. 103-108. In: M.E. Medri; E. Bianchini; O.A. Shibatta \& J.A. Pimenta (eds.). A Bacia do Rio Tibagi. Londrina. 